\title{
Get Rich Syndrome: Examining the Fight against Cybercrime in Enugu State, Nigeria
}

\author{
Ngozi Idemili-Aronu ${ }^{1}$, Ifeyinwa Angela Ajah ${ }^{2}$, Oguejiofo C. P. Ezeanyaa, ${ }^{3, *}$ Joy Chikaodili \\ Omaliko ${ }^{1}$ and Oluchukwu Sunday Nwonovo ${ }^{4}$
}

\author{
${ }^{1}$ Department of Sociology and Anthropology, Faculty of Social Sciences, University of Nigeria, Nsukka, \\ Nigeria \\ ${ }^{2}$ Department of Computer Science, Ebonyi State University, Abakaliki, Nigeria \\ ${ }^{3}$ Humanities Unit, School of General Studies, University of Nigeria, Enugu Campus, Nigeria \\ ${ }^{4}$ Department of Sociology and Anthropology, Faculty of Social Sciences, Enugu State University of Science \\ and Technology, Nigeria
}

\begin{abstract}
Despite the large scale provisions within the Nigerian legal framework that address the issue of cyber frauds, there is an alarming increase in cyber-offences in Nigeria. This necessitated the present study that employed semistructured interviews to draw data from civil servants from grade level twelve and above and business owners aged 40 years and over [ $\mathrm{N}=34]$. The study participants were recruited through a purposive sampling method and data were analyzed thematically. Results show that individuals and different organizations are often hit through direct hacking, malware planting, and many other more sophisticated means by cyber-criminals. The study calls for the Nigerian leaders to reach a consensus on the meaning of cyber fraud, the effects and roles each community must play to reach an agreed goal. Parents need to also balance euphoria in their children with training and preparations for the harsh environments in the real world.
\end{abstract}

Keywords: Cybercrime, Direct hacking, Fight, Malware planting.

\section{INTRODUCTION}

Cybercrime has been identified as one of the major challenges hindering Nigeria from achieving its potentials. The issue of cybercrime and how to combat it has remained a recurrent debate in Nigeria's sociopolitics, yet there seems to be no end in sight. Understandably, cybercrime is neither a peculiar problem to Nigeria nor to any specific country (Okpa, Ajah \& Igbe, 2020; Nnam, Ajah, Arua, Okechukwu \& Okorie, 2019; Ajah \& Onyejegbu, 2019; Adewole, Isiaka, \& Olayemi, 2011). The unique appellation of Nigeria as full of cybercrime and criminals is however promulgated by the many challenges that face the country and the emotional dimensions of styles of crimes perpetrated from the country (Ugwuoke, Ajah \& Onyejegbu, 2020; Adewole, Isiaka, \& Olayemi, 2011; Ajayi, 2016).

It is important to note that the term "cybercrime" is often used in misleading contexts. While cybercrime includes all forms of criminal activities carried out through the internet like cyber espionage, cyberstalking, revenge porn, forgery, hacking or stealing of data, Nigeria is exclusively vested in cyber fraud (Nnam, Effiong, lloma, Terfa \& Ajah, 2021; Abdul-

*Address correspondence to this author at the Humanities Unit, School of General Studies, University of Nigeria, Enugu Campus, Nigeria;

E-mail: oguejiofocpe@gmail.com
Rasheed Ishowo, Muhammed, \& Abdullateef, 2016). Cyber fraud is a type of cybercrime that involves the use of deception to tout and defraud people on the internet (Nnamani, Ilo, Onyejegbu, Ajah, Onwuama, Obiwulu \& Nzeakor, 2021; Jumoke, 2015; ALRawashdeh, Abu-Errub, Areiqat, \& Dbbaghieh, 2012). It requires less technological skills but sufficient social skills to attract and misdirect victims.

According to Eze, Obi and Ajah (2020) and AlShalam (2006), Nigeria is rather vested in cyber fraud while developed countries in the West are vested in other kinds of cybercrimes like cyberstalking, hacking, revenge porn, and cyber espionage. In the real sense of things, Nigeria is not the most active country in cybercrime - China, United States (US), and United Kingdom (UK) have always come before Nigeria. US Federal Bureau of Investigation (FBI) and its Internet Crime Complaint Center have consistently ranked Nigeria 'third" behind US and UK in cybercrimes (Eze, Ajah, Nwonovo \& Atama, 2021; Chinweze, Chukwuemeka, \& Egbegi, 2019).

Nigeria is however more designated as a "country of cybercriminals" in the public domain than any of the Western or Asian countries (Ajah, Uwakwe, Nwokeoma, Ugwuoke \& Nnnamani, 2020; Ajah, 2018; Ajah \& Okpa, 2019; Ajah \& Ugwuoke, 2018; Das \& Nayak, 2013). This is so for two reasons; Nigeria has since suffered at the hands of bad governance and 
victims of Nigerian fraudsters do not only lose their monies, they also suffer from emotional entanglements. First, the impacts of consistent bad leadership across Nigeria since independence like in the economy and healthcare of Nigerian citizens, and the ensuing narratives covering the country paint to the world "a miserably poor and useless country where the leaders heartlessly harm and destroy their own people (Ajah, Nnam, Ajah, Idemili-Aronu, Chukwuemeka \& Agboti, 2021; Ajah, Ajah \& Obasi, 2020; Ajah, Dinne \& Salami, 2020).

With this narrative clouding every mention of Nigeria to non-Nigerians, it is easy to conveniently append everything bad to the country. Second, the primary goal of every Nigerian cyber fraudster is the financial benefit. They are considerably unsophisticated, keen for quick access to victims' cash, and sometimes even annoying in a unique annoying manner. They fit the narrative of "miserably poor Nigeria" and often conjecture their own stories of how miserable their lives and homes are - just to convince and misdirect their victims (Ajah \& Onyejegbu, 2019; Ayofe \& Irwin, 2010; Bamrara, Singh \& Bhatt, 2013).

These "pity-seeking" conjectures often successfully seduce victims and part them with their life savings. This is always painful because the method does not only lure and harm the emotions of victims - it also costs them savings that took very long to build. Danquah and Longe (2011) noted that because it is easy to attribute everything bad to Nigeria in addition to the unique emotions and pains associated with methods of cyber fraudsters from Nigeria, most nonNigerians unconsciously consider Nigeria as the most fraudulent of all countries - even when US and UK are evidently ranked higher than the country.

Nigerians have reacted to this global attribution of cybercrime and cybercrime but these reactions have been rather conflicting (Chinweze, Chukwuemeka, \& Egbegi, 2019; Danquah \& Longe, 2011). After David Cameron's public declaration of Nigeria as "fantastically corrupt," the Nigerian president went on to tell News Channels that he agreed with Cameron and would demand repatriation of funds looted from Nigeria back to Nigeria (Anthony, Obasi, Obi, Ajah, Okpan, Onyejegbu, Obiwulu \& Onwuama, 2021; Olalekan \& Kamarudeen, 2016). Opposition parties in Nigeria vehemently rejected Cameron's assertions and reprimanded the president for espousing such notions (Areh, Onwuama \& Ajah, 2020; Affe, 2010). The actual confliction in response exuded itself in Nigerians' remarks on social media. Nigerians could not agree on the meanings of Cameron's assertion and its implications for the country. With this failure to reach consensus, the chant of Nigeria as a country of cybercrime and cybercriminals yet endured.

These conflicts are proofs that Nigerians have no consensus on the meaning of cybercrime, size of its threats or methods of addressing the threats (Danquah \& Longe, 2011). The implications of this inability of Nigerians to agree on meanings and actions are many - but the graveness of impact is most on the neoeconomy.

Many scholars have studied cybercrime in Nigeria and made valid contributions on impacts and viable rectification measures (Das \& Nayak, 2013; Desai \& Patel, 2013; Folashade \& Abimbola, 2013). What however has not been achieved is a detailed study on how cybercrime affects the success of businesses in the neo-economy and it can be addressed. This gap is what this study intends to fill.

\section{THEORETICAL FRAMEWORK}

The proposed theoretical framework is containment theory. Containment theory was developed by Walter Reckless in 1961. This theory suggests that individuals are pushed and pulled into crime. Pushes are elements that pressure individuals to engage in delinquency while pulls draw individuals away from accepted forms of behavior. The theory states that pushes and pulls are buffered by inner and outer containment. The inner containment includes self-concept, goal orientation, frustration tolerance, and norm commitment and retention (i.e. elements within the individual's self). The outer containment includes the social environment in which the individual resides and reflects socialization within the community (i.e. elements outside one's self) (Onyejegbu, Onwuama, Onah, Okpa \& Ajah, 2021; Cardwell, 2013).

Containment theory asserts that there is an ordering to these elements, with factors of inner containment being developed to address the onset of deviant pushes and factors of outer containment serving as secondary reinforcement mechanisms and buffers against deviant pulls. According to Reckless, we should expect to see factors of inner containment exhibit a strong and primary influence on decision making over the factors of outer containment (Kennedy, 2015).

A situation that may push an individual towards a deviant act is one in which the individual feels some type of pressure to engage in order to escape or 
improve their current situation (Lilly, Cullen \& Ball, 2007). As the individual is self-interested, the presence of the negative situation is pushing them toward a socially undesirable act because they see this act as a way to alleviate their current pain. The only thing keeping the individual from engaging in undesirable behaviour is the presence of strong factors of inner or outer containments (Kennedy, 2015).

In this context, most Nigerian millennials are pushed to cyber fraud by the failures of their imagined futures to come true as they had imagined. These failures make them seek alternatives to bring their dreams to reality and mostly resort to cyber fraud as a quick, but desperate means. The millennials are also pulled to cyber fraud by the lack of societal laws and systems that allow them to express their creativity and get rewarded for doing so. This is seen in how tight the leadership cults in Nigeria are, allowing only a handful of people into leadership positions and keeping the young and innovative millennials out of leadership systems. With the increasing popularity of Nigeria's personality in cyber fraud, a new pull is created that affects the neo-economy and likely the future of Nigeria. This new pull builds a vicious cycle of cybercrime in Nigeria by targeting the foundation of modern economies in Nigeria.

\section{METHODOLOGY}

\section{Design, Study Frame and Sample Size}

This study adopted a cross-sectional survey design. Civil servants from grade level twelve and above and business owners aged 40 years and over [ $\mathrm{N}=34$ ] were selected through the availability and purposive sampling method. The essence of selecting these categories of the respondent was to ensure an integrated in-depth analysis of the topic from both the perspectives of civil servants and business proprietors. To this end, twenty respondents were selected. Consideration was given to the proportional gender representation of the respondents.

\section{Data Collection and Settings}

To gather data for this study, the researcher conducted semi-structured, face-to-face, oral in-depth interviews with all our respondents from April 2021 to May 2021. The researcher prepared an interview guide with specific themes or domains spelt out but made sure the researcher remained as flexible as possible during the interview process. The essence of the interview guide was to rely on sequential probes to pursue leads provided by our respondents. Interviews for this study focused on issues of cybercrime and neoeconomy.

The interview was interactive in nature. The researcher interlaced it with word association or sentence completion where certain statements were made halfway and the respondents were invited to either respond, complete the sentence, or take it up from there. Faced with the need to be sensitive and non-exploitative of our subjects (Mishler, 1986; Punch, 1986), the researcher asked the respondents to respond to her questions in a narrative accounts manner which has been described as capable of providing insights into the connection between life experiences with one's social environment (Pierce, 2003). Each respondent's interview lasted between 65 and 90 minutes.

To capture the feelings, thoughts, perceptions and a panorama view of the respondents, the general question that guided the interview was: "Please tell us how you will describe the level of cybercrime in Nigeria today?" "What would you say that cybercrime has caused Nigerian neo-economy"? And so on and so forth. Finally, the researcher is confident in the validity of our data because when the researcher crosschecked the responses of the respondents, she found that it closely matches her reflective data, most media reports on corruption and available information recorded by anti-corruption agencies.

\section{Analytic Strategy}

The collected qualitative data were analyzed using the manual thematic method, where the responses were transcribed with some catchy phrases retained in their original versions and contexts in the form of extracts or excerpts (see the result section for details).

\section{DISCUSSION OF RESULTS}

\section{The Dimension and Nature of Cybercrime}

Jumoke (2015) observed that cybercrime, previously relatively unknown to Nigerians, has suddenly become domesticated. Chinweze, Chukwuemeka and Egbegi (2019), Ayofe and Irwin (2010), had reported on the sudden rise in cybercrimes in Nigeria. In the opinions of the respondents, cybercrime in contemporary Nigeria is alarming. A 30year-old respondent who shared the view of a rising trend explained that the reason is because cyber crimes are no longer viewed by society as illegal. 
Following respondents' choice of vocabularies, one concept emerged which define the widespread of cybercrime. One of the respondents has said:

Nwanne (my brother)...money-making blood dey run for our country today! (money-making desire is haemorrhaging) because of wetin dey happen (what is happening) on daily defraud of people".

The respondents rated cybercrime the highest among all other crimes in Enugu, only trailing behind kidnapping and herdsmen attacks. This is in line with Das and Nayak (2013) who notes that there has been a rise in unemployment which is pushing the teeming unemployed youths to frauds. This fraud is seen more importantly in the areas of the political, religious, social, economic and cultural life of Africa.

\section{The Motives Behind Cybercrime}

In the words of Otu, Nnam and Uduka (2018), the motive behind a particular criminal conduct is of resounding relevance to researchers'. It is particularly germane in the study of cybercrime because it delves deeply into the direct and indirect, immediate and remote reasons why people engage in a sustained defraud of people. From the respondents' accounts and building upon the works of previous scholars who have carefully analysed the motives of other categories of crimes (see Ugwuoke, Ajah \& Onyejegbu, 2020; Otu, Nnam \& Uduka, 2018; Egbegi, Ajah \& Ogbonnaya, 2018; Evely, 2018; Ukwayi \& Okpa, 2017; Mathias \& Ajah, 2017; Emeh, 2017), the researcher constructed the following classification schemes consistent with controlling themes identified within the motives/reasons by our subjects.

a) Justification: a sad tale (e.g. mistreatment) and denial of injury

b) Excuse: scapegoating

c) Apology.

\section{Justification}

\section{Sad Tale}

According to Otu, Nnam and Uduka (2018); Pogrebin, Poole and Martinez (2012), 'sad tale depicts an account of the number of disappointing experiences, conditions or circumstances which both collectively and cumulatively are used to explain and justify the actor's illegal behavior'. This is a kind of whipping up sentiment or what we refer to here borrowing from
Sykes and Matza (1957) as 'appealing to higher authority'. The subjects presented sad tales which invariably focused on poor economic conditions and too many societal expectations.

One of the respondents has this to say:

I have been in search of work since 2002 after graduating from the university without any hope in sight. Look at me, I feel ashamed being in the midst of my friends because of shame...

Another justifying participation of youth adds:

Your parents expect you to take care of them immediately after you graduate from university. How do you fulfil such expectations when you don't have a meaningful job?

Perhaps that is while Ajah and Onyejegbun (2019) presented a very inclusive argument which noted that 'low literacy level of some Nigerians, pervasive poverty, leadership failure, among others - breed ground for cyber-frauds. In many ways, Ajah and Onyejegbun points cover most causes of cybercrimes in Nigeria.

\section{Scapegoating}

'Scapegoating is all about shifting one's blameworthiness to others for one's untoward behaviour' (Otu, Nnam \& Uduka, 2018). 'Scapegoating becomes an excuse in cybercrimes because of the contextual opportunity for the fraudsters to shift personal liability to the victims. The fraudster contends that his or her action was a result of the attitude and lifestyle of the victim. Scapegoating is saying that victims of cyber-frauds were the cause of their being victimised-a kind of victim precipitation. The offenders in the following example recognised the illegality of their behaviours by demeaning and denying responsibility, shifting the blame to the attacked victims' (Otu, Nnam \& Uduka, 2018).

A respondent notes:

The target is Europeans who stole from our forefathers. The youths are just repatriating what they stole from us.

Another respondent adds:

This is caused by the failure of the government to provide an enabling environment for Nigerians to thrive. 


\section{Appropriate Sanction}

The respondents were asked to suggest, in their own views, the best measures that could help prevent and control cybercrimes in Nigeria. Again, the vocabularies of sanction/punishment respondents used are classified into two categories, namely: hypotheticalhypocritical pessimism and optimism (Otu, Nnam \& Uduka, 2018).

\section{Hypothetical and Hypocritical Pessimism}

The researcher describes this to mean an expression of a bleak hope on the prospect of any sanction or sanctions effectively tackling cyber crimes in Nigeria. Respondents are of the view that cybercrimes will not come to an end, notwithstanding the sanction or sanctions in place' (see Otu, Nnam \& Uduka, 2018). Some of their views and feelings are expressed below.

A victim laments:

No bros! Nobody fit stops cybercrime because some people wey supposed dey fight it dey support them (Brother, no one can stop cybercrime because quite a number of people who are supposed to be fighting it is supporting it).

This is in line with the view of Ajayi (2016) who sees the attitude of government's negligence to be oppressive, discriminative, and a major factor that causes of cybercrimes.

\section{Hypothetical and Hypocritical Optimism}

'Optimism involves expressing positive hope that a particular action or inaction will yield positive value or outcome. It suggests keeping hope alive, even in the face of a gloomy circumstance' (Otu, Nnam \& Uduka, 2018; Ajah, Nwokeoma \& Okpan, 2017). Below are typical hypothetical/hypocritical optimistic suggestions expressed by some of our respondents.

A respondent out of anger and frustration says:

I rather suggest imprisonment for the cyber-offenders. I think a 28-year-imprisonment go dey ok. (will be appropriate).

Another respondent who has suffered much opines:

Me (I) suggest life imprisonment, knowing very well that one day the person fit (may) be pardoned. But death... no! no! no!

\section{DISCUSSIONS}

Two foundational things companies and businesses of the neo-economy require to innovate, survive, and grow are trust and financial investments. Trust connotes high-level confidence that these businesses and companies can be truthful, useful, and should be given trials to prove their relevance (Timothy, 2018). This trust is expected of customers and partners. With trust from Nigerian users in the market, neo-economy businesses can reach their target users at ease, help solve users' pain points and generate revenues to scale the businesses (Tan, 2009). But when trust is exculpated, target users consider the businesses to be fraudulent by default. Then stay away from such businesses and stick to old manual processes - even when the neo-economy businesses offer better values to them. In such scenarios, neo-economy businesses find it hard to sell, scale or even survive. The businesses eventually die off and great opportunities become lost.

At the current state of development, Nigeria has very few citizens who understand the neo-economy and have funds to invest in it. The greatest numbers of people that understand the neo-economy are outside Nigeria. They live, work and hold citizenships in Europe, Asia, and North America. These are the people that have also grown to believe Nigeria is home to criminals and cyber fraudsters. They consider every Nigeria as a poor, criminal-minded and cyber fraudster by default. This epithet of fraudsters and criminals have made it extremely difficult for businesses in the new economy to raise the funds required to innovate, survive and fully embrace market opportunities. The biggest consequences of Nigeria's huge profile in cyber fraud is the lack of trust and support required from local Nigerian markets for neo-economy businesses to succeed - and the extreme reluctance of foreign investors to trust and invest in Nigerian neo-economy businesses due to the belief that all opportunities or businesses from Nigeria are fraud (Chinweze, Chukwuemeka, \& Egbegi, 2019). The key result of these is that Nigeria loses the opportunities of the neoeconomy era while the same economy makes peoples' lives better and thrive in other regions of the world.

\section{CONCLUSION}

The internet has brought the world to one "public hall," a place where everyone is connected to everyone. This is the foundation of the future and most businesses have already taken every element of their 
existence to the internet. These businesses constitute a new form of the economy called the neo-economy. The neo-economy proves to benefit humanity greatly especially in making human lives better. In Nigeria, the neo-economy is young and will not succeed if financial investors from developed countries in Europe, Asia, and North America do not embrace business opportunities and invest their money in Nigeria's neoeconomy. This reluctance to invest was created by Nigeria's infamous profile in cyber fraud. Therefore, Nigerian leaders need to reach a consensus on the meaning of cyber fraud, its effects and the roles each community must play to reach an agreed goal. Parents need to also balance euphoria in their children with training and preparations for the harsh environments in the real world.

\section{REFERENCES}

Abdul-Rasheed Ishowo, S. L., Muhammed, L. A. \& Abdullateef, Y. R. (2016). Cybercrime and Nigeria's external image: A critical assessment. Africology: The Journal of Pan African Studies, 9(6), 119-132.

Adewole, K. S., Isiaka, R. M. \& Olayemi, R. T. (2011). An inquiry into the awareness level of cyber security policy and measures in Nigeria. Journal of Science and Advanced Technology, 1(7), 91-96

Affe, M. (2010, June 15). Online shopping portal decries prevalence of internet fraud. The Punch Newspaper, Tue, pp. 25.

Ajah, B. O, Uwakwe, E. E., Nwokeoma, B. N., Ugwuoke C. O., \& Nnnamani, R. G. (2020). Ameliorating the plight of awaitingtrial inmates in Ebonyi State, Nigeria through reasonable bail condition. Pertanika Jounal of Social Sciences \& Humanities, 28 (4), $2897-2911$. https://doi.org/10.47836/pjssh.28.4.22

Ajah, B. O. (2018). Educational training of inmates in Awka and Abakaliki Prisons, Nigeria Journal International Journal of Criminal Justice Sciences. 13 (2), 299-305

Ajah, B. O., \& Okpa, J. T. (2019). Digitization as a solution to the problem of awaiting-trial inmates in Ebonyi State, Nigeria. International Journal of Criminal Justice Sciences, 14 (2), 199-207.

Ajah, B. O., \& Ugwuoke, C. O. (2018). Juvenile Justice Administration and Child Prisoners in Nigeria. International Journal of Criminal Justice Sciences, 13 (2), 438-446.

Ajah, B. O., Nnam, M. U., Ajah, I. A., Idemili-Aronu, N., Chukwuemeka, O. D., \& Agboti, C. I. (2021). Investigating the awareness of virtual and augmented realities as a criminal justice response to the plight of awaiting-trial inmates in Ebonyi State, Nigeria. Crime, Law and Social Change. https://doi.org/10.1007/s10611-021-09988-5

Ajah, B.O., Ajah, A.I., \& Obasi, C. O. (2020). Application of Virtual Reality (VR) and Augmented Reality (AR) in the Investigation and Trial of Herdsmen Terrorism in Nigeria. International Journal of Criminal Justice Sciences, 15 (1), 1-20.

Ajah, B.O., Dinne, C.E., \& Salami, K. K. (2020). Terrorism in Contemporary Nigerian Society: Conquest of Boko-Haram, Myth or Reality. International Journal of Criminal Justice Sciences, 15 (1), 312-324.

Ajah, O. B., \& Onyejegbu, D. C. (2019). Neo-Economy and Militating Effects of Africa's Profile on Cybercrime. International Journal of Cyber Criminology, 13 (2), 326-342.
Ajayi, E. F. G. (2016). Challenges to enforcement of cyber-crimes laws and policy. Journal of Internet and Information Systems, 6(1), 1-12. https://doi.org/10.5897/JIIS2015.0089

AL-Rawashdeh, B. S., Abu-Errub, A. M., Areiqat, A.Y. \& Dbbaghieh, M. (2012). Information technology role in reducing ebankings.

Al-Shalam, A. (2006). Cyber crime fear and victimization: An analysis of a national survey. Ph.D dissertation submitted to Mississippi State University.

Anthony, E.O., Obasi, C.O., Obi, D.O., Ajah, B.O., Okpan, O.S., Onyejegbu, C.D., Obiwulu, A. C., \& Onwuama, E. M. (2021). Exploring the reasons for perennial attacks on churches in Nigeria through the victims' perspective. HTS Teologiese Studies/Theological Studies, 77(1), a6207. https://doi.org/10.4102/hts.v77i1.6207

Areh, C. E., Onwuama, E. M., \& Ajah, B. O. (2020). Social consequences of wife-battering in Ogbaru and Onitsha north local government areas of Anambra State, Nigeria. FWU Journal of Social Sciences, 14 (4), 80-92. https://doi.org/10.51709/FW12727

Ayofe, A. N., \& Irwin, B. (2010). Cyber security: Challenges and the way forward. GESJ: Computer Science and Telecommunications, 6(29), 56-69.

Ayofe, A. N., \& Irwin, B. (2010). Cyber security: Challenges and the way forward. GESJ: Computer Science and Telecommunications, 6(29), 56-69.

Bamrara, A., Singh, G., \& Bhatt, M. (2013). Cyber attacks and defense strategies in India: An empirical assessment of banking sector. International Journal of Cyber Criminology, 7(1), 49-61. https://doi.org/10.2139/ssrn.2488413

Chinweze, U. C., Chukwuemeka, O. D., Egbegi, F. R. (2019). An exploratory study of cybercrime in the contemporary Nigeria value system. European Journal of Social Sciences Studies, 4(3), 131-141.

Danquah, P., \& Longe, O. B. (2011). Cyber deception and theft: An ethnographic study on cyber criminality from a Ghanaian perspective. Journal of Information Technology Impact, 11(3), 169-182.

Das, S., \& Nayak, T. (2013). Impact of cybercrime: Issues and challenges. International Journal of Engineering Sciences \& Emerging Technologies, 6(2), 142-153.

Eze, O. J., Obi, D. O., \& Ajah, B. O. (2020). Nigerian criminal justice system and victims of crime neglect in Enugu Urban. FWU Journal of Social Sciences, 14 (3), 41-53. https://doi.org/10.51709/FW1272J/fall2020/4

Eze, O.J., Ajah, B.O., Nwonovo, O. S., \& Atama, C.S. (2021).Health sector corruption and COVID-19 outbreak: evidence from Anambra and Enugu States, Nigeria. Journal of Contemporary African Studies. https://doi.org/10.1080/02589001.2021.1921129

Folashade B. O. \& Abimbola, K. A. (2013). The nature, causes and consequences of cybercrime in tertiary institutions in ZariaKaduna State.

Franz-Stefan, G. (2010). Africa's Cyber WMD. Foreign Policy. Retrieved from https://foreignpolicy.com/2010/03/24/africascyber-wmd.

Jaishankar, K. (2007). Cyber criminology: Evolving a novel discipline with a new journal. International Journal of Cyber Criminology, 1(1), 1-6.

Jansen, J. \& Leukfeldt, R. (2016). Phishing and malware attacks on online banking customers in the Netherlands: A Qualitative Analysis of facto.

Jumoke, A. L. (2015, March 5). SMEs hardest hit by cybercrime, as $60 \%$ of Nigerian businesses suffer attacks. Business Day Report, P3. 
Mathias, B. A. \& Ajah, B. O. (2017). Understanding the Gender Dimensions of Cyberbullying among Undergraduates in Nigeria. Nigeria: Ahmadu Bello University Press Limited, Zaria.

Nnam, M. U., Ajah, B. O., Arua, C. C., Okechukwu, G., \& Okorie, C. O. (2019). The War must be Sustained: An Integrated Theoretical Perspective of the Cyberspace-Boko Haram Terrorism Nexus in Nigeria. International Journal of Cyber Criminology, 13 (2), 379-395.

Nnam, M.U., Effiong, J.E., Iloma, D.O., Terfa, I.M., \& Ajah, B.O. (2021) Hazardous drinking and the dark triad: an antidote for manipulative behaviour among students. Current Psychology, 40(4), 1-7. https://doi.org/10.1007/s12144-021-01680-0

Nnamani, G.R., Ilo, K.O., Onyejegbu, D. C., Ajah, B.O., Onwuama, M. E., Obiwulu, A. C., \& Nzeakor, O. F. (2021). Use of Noncustodial Measure and Independent Monitoring Body as
Panacea to Awaiting-Trial Problems in Ebonyi State, Nigeria. International Journal of Criminal Justice Sciences, 16 (1), 5163.

Okpa, T. J., Ajah, O. B., \& Igbe, E J. (2020). Rising Trend of Phishing Attacks on Corporate organisations in Cross River State, Nigeria. International Journal of Cyber Criminology 14 (2), 460-478.

Onyejegbu, D.C., Onwuama, E.M., Onah, C.I., Okpa, J.T., \& Ajah, B.O. (2021). Special Courts as Nigerian Criminal Justice Response to the Plight of Awaiting Trial Inmates in Ebonyi State, Nigeria. International Journal of Criminology and Sociology, 10, 1172-1177 https://doi.org/10.6000/1929-4409.2021.10.136

Ugwuoke, C. O., Ajah, B. O., \& Onyejegbu, C. D. (2020). Developing patterns of violent crimes in Nigerian democratic transitions. Aggression and Violent Behavior, 53, 1-8. https://doi.org/10.1016/j.avb.2020.101457

(C) 2021 Idemili-Aronu et al.; Licensee Lifescience Global.

This is an open access article licensed under the terms of the Creative Commons Attribution License (http://creativecommons.org/licenses/by/4.0/) which permits unrestricted use, distribution and reproduction in any medium, provided the work is properly cited. 